\title{
Results of the First Austrian Multidisciplinary Expert Panel on Controversies in Local Treatment of Breast Cancer
}

\author{
Michael Knauer ${ }^{\mathrm{a}} \quad$ Michael Gnant $^{\mathrm{b}} \quad$ Florian Fitzal $^{\mathrm{b}}$ on behalf of the Panel Members \\ of the St. Wolfgang ACO/ASSO Senology Panel 2011
}

aBreast Cancer Center, Department of Surgery, Sisters of Charity Hospital, Linz,

${ }^{\mathrm{b} C}$ Comprehensive Cancer Center, Department of Surgery, Medical University Vienna, Austria

\author{
Keywords \\ Breast cancer: local therapy, surgery, radiotherapy . \\ Expert panel
}

\section{Summary}

At the first Austrian multidisciplinary expert panel on controversies in local treatment of breast cancer, 22 experts of all relevant disciplines discussed current areas of debate (surgery of the breast, surgery and pathology of the axilla, reconstructive surgery, radiotherapy, and imaging) in local therapy. The most controversial area of debate was the area of axillary surgery. The panel agreed that it was no longer necessary to perform completion axillary lymph node dissection (ALND) when micrometastases are diagnosed in the sentinel lymph node. The only prospective trial comparing patients with sentinel node macrometastases with or without completion ALND had to be terminated early due to failure in sufficient patient recruitment. As long as the frequently discussed issues have not been solved and in light of the lack of any clear level 1 evidence, the panel decided not to recommend omitting axillary dissection in patients with 1 or 2 macrometastases meeting the inclusion criteria of the ACOSOG Z0011 trial. The Austrian panel similarly decided not to recommend omitting axillary dissection in patients with macrometastases and low-risk breast cancer in general. These decisions reflect the increasing skepticism of the scientific community against rapidly shifting paradigms without sufficient and clear evidence.

\author{
Schlüsselwörter \\ Mammakarzinom: Lokaltherapie, Chirurgie, \\ Strahlentherapie $\cdot$ Expertenpanel
}

\section{Zusammenfassung}

Beim ersten österreichischen interdisziplinären Expertenpanel zum Thema "Kontroversen bei der Lokaltherapie des Mammakarzinoms" diskutierten 22 Experten aus allen relevanten Disziplinen Themen aus aktuellen Spannungsfeldern (Chirurgie der Brust, Chirurgie und Pathologie der Axilla, rekonstruktive Chirurgie, Strahlentherapie und Bildgebung). Das am kontroversesten diskutierte Thema war die Chirurgie der Axilla. Das Panel war der Meinung, dass eine komplettierende Axilladissektion bei Mikrometastasen im Wächterlymphknoten (Sentinel Node) nicht mehr notwendig ist. Die einzige prospektive Studie, die bei Patientinnen mit Makrometastasen im Sentinel Node die Axilladissektion randomisiert untersuchte, musste aufgrund unzureichender Rekrutierung frühzeitig geschlossen werden. Bis die häufig diskutierten Probleme in dieser Studie geklärt sind und in Ermangelung von klarer Level-1-Evidenz hat sich das Panel dazu entschieden, den Verzicht auf die Axilladissektion bei Patientinnen mit 1-2 Makrometastasen, die den Einschlusskriterien von ACOSOG Z0011 entsprechen, nicht zu empfehlen. Ebensowenig wurde der Verzicht auf Axilladissektion bei Patientinnen mit Makrometastasen und biologischem Low-risk-Karzinom im Allgemeinen empfohlen, was die zunehmende Skepsis der wissenschaftlichen Gemeinschaft gegenüber einem allzu schnellem Paradigmenwechsel ohne ausreichende und klare Evidenz widerspiegelt.

\section{KARGER \\ Fax +497614520714 \\ Information@Karger.de}

www.karger.com (c) 2012 S. Karger GmbH, Freiburg

1661-3791/12/0071-0061\$38.00/0

Accessible online at:

www.karger.com/brc
Prof. Dr. med. Florian Fitzal

Medizinische Universität Wien

Universitätsklinik für Chirurgie

Währinger Gürtel 18-20, 1090 Wien, Austria

Tel. +43 1 40400-5621, Fax -5641

florian.fitzal@meduniwien.ac.at 


\section{Introduction}

Within the last few years, some important and potentially practice changing clinical trials in the field of local therapy of early breast cancer have been reported. The American College of Surgeons Oncology Group (ACOSOG) Z0011 trial suggested that in patients with a clinically negative axilla and 1 or 2 macrometastases in the pathological workup, a completion axillary dissection can safely be omitted without adversely affecting prognosis [1]. Also, the impact of micrometastases on outcomes and treatment decisions has been challenged [2]. Furthermore, new trials of partial breast irradiation and hypofractionated whole breast irradiation showed similar results compared with conventional whole breast radiotherapy [3-5].

These results prompted the organizers of the joint annual meeting of the Austrian Society of Surgical Oncology (ACO ASSO) and the Austrian Society of Senology (ÖGS) to organize a panel discussion on current areas of debate regarding local treatment of breast cancer. The meeting took place in St. Wolfgang, October 6-8, 2011. The multidisciplinary panel consisted of 22 Austrian experts from all relevant disciplines treating breast cancer, i.e. surgeons, gynecologists, radiation and medical oncologists, pathologists, reconstructive surgeons, and radiologists in accordance with their affiliated societies. After evidence on various issues regarding local therapy was presented throughout the meeting, the panel had to address 22 questions that had emerged from previous discussions and had been submitted to the panelists before the meeting. The aim was to give daily practice oriented clinical decision-making advice for physicians treating breast cancer by assessing the evidence and by providing expert opinion on the most controversial topics in local treatment. The panel was supported by the following Austrian societies: radiology (ÖGR), gynecology and obstetrics (ÖGGG), senology
(ÖGS), surgery (ÖGC), radiooncology (ÖGRO), plastic and reconstructive surgery (ÖGPAR), pathology (ÖGP), and surgical oncology (ACO ASSO). At least one member of each society was elected into the panel.

\section{Surgery of the Breast}

A strong majority considered a $1 \mathrm{~mm}$ tumor free margin as sufficient surgical treatment. Furthermore, still the majority of the panel even accepted a resection margin 'not touching the ink' without additional risk factors in breast conserving surgery to be sufficient to omit further re-excisions. This recommendation is in concordance with a recent meta-analysis by Houssami et al. [6], that evaluated 1,026 cases of local recurrence in 14,571 patients. In contrast, the panel was critical about the acceptance of a $2 \mathrm{~mm}$ margin in ductal carcinoma in situ (DCIS), which is not in concordance with the 2009 metaanalysis of 4,660 patients by Dunne et al. [7], when a $2 \mathrm{~mm}$ margin seemed to be as sufficient as a $5 \mathrm{~mm}$ margin regarding in-breast local recurrences.

Oncoplastic surgery represents the integration of reconstructive surgery techniques into cancer surgery for improvement of cosmetic outcomes without compromising local control. In recent years, several oncoplastic techniques have been widely adopted in many Austrian breast centers. The panel strongly supported the view that for patients with a planned resection of $25 \%$ or more of the breast tissue, as clinically estimated by the treating surgeon, the use of oncoplastic techniques should be recommended. However, there is no level 1 evidence for this approach.

Neoadjuvant chemotherapy (nCT) is increasingly being used not only for improvement of breast conservation rates, but also aiming at preoperative evaluation of tumor biology in order to assess prognostic and predictive markers of cytotoxic

Table 1. Main results of the multidisciplinary panel

\begin{tabular}{|c|c|}
\hline Surgery of the breast & $\begin{array}{l}\text { acceptable resection margin: 'not touching the ink' for invasive cancer } \\
\text { recommendation for oncoplastic surgical techniques in case of resection of }>25 \% \text { of breast tissue } \\
\text { acceptance of resection within new tumor extent after nCT }\end{array}$ \\
\hline Axilla surgery and pathology & $\begin{array}{l}\text { axillary dissection not recommended in case of isolated tumor cells or micrometastasis in the sentinel node } \\
\text { no clear recommendation supporting omission of ALND in the presence of macrometastases in the sentinel node } \\
\text { acceptance of SNB after nCT in the event of partial or complete clinical remission of the main cancer }\end{array}$ \\
\hline Reconstructive surgery & $\begin{array}{l}\text { nipple-sparing mastectomy accepted as safe and valid option } \\
\text { no recommendation for immediate breast reconstruction with implants for patients with postmastectomy } \\
\text { radiotherapy }\end{array}$ \\
\hline Radiotherapy & $\begin{array}{l}\text { recommendation of postmastectomy radiotherapy in patients with } 1-3 \text { positive lymph node and an additional } \\
\text { risk factor } \\
\text { option of avoiding radiotherapy for low risk patients above the age of } 70 \text { in certain cases } \\
\text { intraoperative radiotherapy is an option for replacement of external boost } \\
\text { no recommendation for hypofractionated or partial breast radiotherapy as clinical routine standard }\end{array}$ \\
\hline Imaging & breast MRI as staging tool not recommended for all cases of breast cancer \\
\hline
\end{tabular}
$\mathrm{nCT}=$ neoadjuvant chemotherapy; ALND = axillary lymph node dissection; $\mathrm{SNB}=$ sentinel node biopsy; MRI = magnetic resonance imaging. 
therapy. The panel strongly supported the possibility of resecting according to the radiologically assessed post-neoadjuvant tumor extent in case of treatment response and subsequent possibility of breast conserving therapy. On the other hand, the panel did not support the recommendation for a mastectomy en principe for the (rare) cases of tumor progression during neoadjuvant treatment due to lack of substantial data, except from one retrospective study [8].

\section{Surgery and Pathology of the Axilla}

A large retrospective study on the topic of micrometastasis from the Netherlands Cancer Registry showed that isolated tumor cells and micrometastases were associated with a worse outcome at 5 years in patients who did not receive adjuvant therapy [9]. The randomized NSABP B-32 study also demonstrated a significant overall survival difference between patients with and without occult metastases. However, the absolute difference was only $1.2 \%$ [10]. In an era where most patients receive some kind of adjuvant therapy, the diagnosis of isolated tumor cells in the sentinel node (SN) does not influence surgical or adjuvant treatment anymore. Therefore the panel agreed that it was no longer necessary to look for isolated tumor cells. The panel, however, accepted the pathologists' recommendation for using immunohistochemistry (IHC) to improve the detection of metastases, e.g. from lobular cancer. In concordance with the 2011 consensus recommendations from the St. Gallen panel, the panel generally accepted that micrometastases in the SN (up to $2 \mathrm{~mm}$ ) were not an indication for completion axillary lymph node dissection (ALND) [11].

The recently published ACOSOG Z0011 trial is one of the most controversial, yet possibly practice changing trials for breast surgeons in the last decade [1]. The study showed that in selected postmenopausal patients with clinically node negative T1/2 tumors treated with breast conserving surgery, adjuvant whole-breast radiotherapy and adequate systemic therapy, the omission of axillary dissection for patients with 1 or 2 macrometastases in the SN did not adversely affect prognosis at a follow-up of 6.3 years.

However, in contrast to the St. Gallen recommendations, the panel provided no clear recommendation supporting the omission of ALND in the presence of macrometastases in the SN, as reported from the Z0011 study: only half of the panel members supported this option for patients meeting the Z0011 inclusion criteria and even fewer members voted for this option in all low risk patients, i.e. postmenopausal status, positive hormone receptors, negative Her2 status, histological grade $1 / 2$, low $\mathrm{Ki}-67$. It is worth mentioning that almost one third of the panel members abstained from voting, reflecting the controversial issues of a single study that did not meet target accrual and where the exact extensions of radiation fields have not been reported yet. Furthermore the Z0011 study has several issues regarding patient accrual, data quality regarding follow-up and loss of patients as well as the fact that $41 \%$ of included patients had only micrometastases, comprising a subgroup that would not be scheduled for completion ALND anymore, which is mainly an effect of the results of Z0011 study.

The panel unanimously discouraged the general omission of ALND for all sentinel macrometastases and did neither support the routine use of nomograms to predict for the status of non-SN with the aim of omitting ALND.

Since clear evidence is lacking about the timing of sentinel node biopsy (SNB) around neoadjuvant chemotherapy, the panel accepted the possibility of performing SNB after nCT in the event of partial or complete clinical remission of the main cancer within the breast and the absence of clinically positive axillary lymph nodes before ALND after nCT. Data supporting this approach is limited to several large retrospective series and meta-analyses, while SNB before $\mathrm{nCT}$ is considered to be standard of care [12].

\section{Reconstructive Surgery}

A vast majority of the panelists accepted the technique of nipple-sparing mastectomy as a safe and valid option, if subareolar frozen sections do not show tumor involvement or preoperative imaging shows a distance of more than $2 \mathrm{~cm}$ between the tumor and the nipple-areola-complex. However, frozen section should be recommended as standard while preoperative imaging should only be seen as preoperative decision guidance.

Since more patients are being scheduled for postmastectomy radiotherapy in recent years, after the results of the 2005 Early Breast Cancer Trialists' Collaborative Group (EBCTCG) overview have been published [13], and radiotherapy to prosthetic implants causes a high number of capsule contractions and postsurgery infections, the panel did not recommend immediate breast reconstruction with implants as a suitable option for these patients. On the other hand, the panel was almost exactly split on whether any reconstructive operation should be avoided if the $\mathrm{SN}$ is positive. A positive $\mathrm{SN}$ is increasingly leading to postmastectomy radiotherapy, that would compromise cosmetic outcome of implant reconstruction and in some cases also after autologous reconstruction. However, in case of a positive SNB the reconstructive material should be primarily autologous.

\section{Radiotherapy}

In clear view of the ongoing controversy regarding postmastectomy radiation in patients with $1-3$ positive axillary nodes [13], the panel strongly supported postmastectomy radiotherapy in these patients, if one of the following risk fac- 
tors are present: lymphovascular invasion, premenopausal status, Her2-positive, or triple-negative tumors. This recommendation also reflects the ongoing paradigm shift from mainly stage based risk assessment to biology driven risk evaluation for individual patients.

In elderly patients above the age of 70 with endocrine responsive tumors up to $1 \mathrm{~cm}$ in diameter receiving adequate endocrine therapy, a majority of the panel supported the option of avoiding adjuvant radiotherapy after breast conserving surgery in certain cases. It is worth mentioning that the panel did not recommend avoiding radiotherapy in these patients in general, as prospective trials clearly demonstrated a significant improvement with regard to local recurrence even in low-risk patients [14].

Several studies have highlighted new radiotherapy modalities such as intraoperative or partial breast irradiation (PBI) or hypofractionated whole breast radiotherapy as alternative to conventionally fractioned treatment $[3-5,15]$. The panel clearly supported the use of intraoperative radiotherapy as an alternative to an external boost to the tumor bed, whereas it did not support hypofractionated radiotherapy or PBI as acceptable standard for routine clinical use. However, the facts that more than a third of the panel abstained from voting and that only a few panel members were radiooncologists might have influenced this vote, since in some guidelines this technique is considered a reasonable standard approach.

\section{Imaging}

Since many centers and radiologists in private practice are increasingly using magnetic resonance (MR) mammography for staging in breast cancer and prospective studies showed a detrimental effect of MR imaging (MRI) on breast conserving therapy rates without given benefit $[16,17]$, it was strongly discouraged by the expert panel that this imaging method should be used for every type of breast cancer. This statement is in accordance to the German 2008 multidisciplinary S3 guidelines for diagnosis, treatment and follow-up care of breast cancer [18] (http://www.senologie.org/download/pdf/ s3_ll_mammaca_11_02_2008.pdf).

\section{Summary and Discussion}

At the first Austrian multidisciplinary expert panel on controversies in local treatment of breast cancer, 22 experts of all relevant disciplines (surgical oncology, gynecology, radiation oncology, radiology, medical oncology, and pathology) discussed current areas of debate (surgery of the breast, surgery and pathology of the axilla, reconstructive surgery, radiotherapy and imaging) in local therapy. All relevant Austrian societies sent at least one delegate to this panel (ÖGS, ÖGC, ÖGGG, ÖGR, ÖGP, ÖGRO, ÖGPAER, ACO ASSO).
The panel consisted of 5 surgical oncologists, 3 gynecologists, 3 radiation oncologists, 4 medical oncologists, 3 reconstructive surgeons, 2 pathologists and 2 radiologists.

The panel accepted a resection margin 'not touching the ink' without additional risk factors in breast conserving surgery to be sufficient to omit re-excisions for invasive cancers. Oncoplastic techniques should be included in decision making if more than $25 \%$ of breast tissue has to be resected. After neoadjuvant therapy surgical resection may be planned within the new radiologically defined tumor border. For reconstructive surgery, the panel agreed that nipple sparing mastectomy was a safe option and in case of a positive SN, surgeons should be cautious about the use of reconstructive operations. Regarding radiotherapy, the panelists supported the use of postmastectomy radiotherapy in 1-3 positive nodes when an additional risk factor is present. Hypofractionated therapy might not be used for clinical routine cases at the moment, whereas intraoperative radiotherapy could be given as alternative to the external boost to the tumor bed. The panel voted against the routine use of breast MRI for staging in general for every type of breast cancer.

The most controversial area of debate, however, was the area of axillary surgery. The panel agreed that it was no longer necessary to perform completion ALND when micrometastases are diagnosed in the SN. This is in line with the recommendations from the St. Gallen consensus panel. Furthermore recent studies suggest that tumor biology as assessed by multigene assays such as the 70-gene profile (MammaPrint ${ }^{\circledR}$ ) or the 21-gene recurrence score (Oncotype Dx ${ }^{\circledR}$ ) has a higher prognostic impact than nodal status in multivariate retrospective analyses, which will very likely further reduce the clinical usefulness of micrometastases [19, 20].

Macrometastases may be a sign of higher cancer burden due to a longer time period between the onset and the diagnosis of cancer rather than a sign of high recurrence risk in many cases. Martelli et al. [21] showed that omitting axillary dissection in clinically node-negative low-risk patients above the age of 70 yields similar oncologic outcome without an increase in local recurrence rates. The IBCSC 10-93 study showed similar results [22]. The only prospective trial comparing patients with SN macrometastases with or without completion ALND had to be terminated early due to failure insufficient patient recruitment [1]. Some centers even included only 1 patient per year. Only $60 \%$ of all patients had macrometastases, while the others had only micrometastases in their SN. The final analysis demonstrated a non-significant difference in axillary, in-breast and distant relapse free survival as well as in overall survival. However, it should be mentioned that axillary failure was almost doubled in patients without axillary complete dissection $(0.5$ vs. $0.9 \%)$. In breast recurrences were more than two times higher in patients after axillary dissection (3.1 vs. $1.4 \%$ ), suggesting significant differences in biology between the two groups. One of these factors might be the $10 \%$ absolute increased incidence of lymphovascular invasion in the 
ALND group. L1-status is known to be one of the strongest prognostic factors for oncologic outcome and may thus have led to a severe selection bias [23]. Another important finding is that $27 \%$ of all patients with ALND had additional macrometastases in non-sentinel nodes. The low axillary recurrence rate in patients without ALND, however, suggests that adjuvant radiotherapy and systemic therapy may have killed some of the non-removed macrometastases. In contrast, Fisher et al. [24] were able to demonstrate that AD did not improve oncologic outcome after mastectomy even in the absence of radiotherapy in the NSABP-B04 trial, suggesting an important host effect in treating un-removed lymph node macrometastases.

As long as these issues have not been solved and in light of the lack of any clear level 1 evidence, the panel decided not to recommend omitting $\mathrm{AD}$ in patients with 1 or 2 macrometastases meeting the inclusion criteria of the ACOSOG Z0011 trial. The Austrian panel similarly decided not to recommend omitting axillary dissection in patients with macrometastases and low-risk breast cancer in general, i.e. postmenopausal status, positive hormone receptors, negative Her2 status, histological grade 1/2, low Ki-67, due to lack of any kind of prospective evidence for this special subgroup of patients. These decisions reflect the increasing skepticism of the scientific community against rapidly shifting paradigms without sufficient and clear evidence.

This decision stands to some extent in contrast to the final St. Gallen recommendations. Although the St. Gallen panel voted strongly against omitting axillary complete dissection in patients with macrometastases in general, the authors sug- gested this possibility in some patients fulfilling the ACOSOG Z0011 criteria. This was the first time in St. Gallen history that such a strong recommendation was based on one prospective trial without sufficient statistical power and early trial stopping due to recruitment failure.

\section{Disclosure Statement}

The authors declare no conflict of interest.

\section{Acknowledgements}

Panel members are listed below in alphabetical order. We would like to thank all panel members for providing input for the multidisciplinary panel.

Rupert Bartsch, Peter Dubsky, Florian Fitzal, Manfred Frey, Richard Greil, Thomas Helbich, Michael Hubalek, Raimund Jakesz, Karin Kapp, Michael Knauer, Rupert Koller, Sigurd Lax, Walter Neunteufel, Angelika Reiner-Concin, Roland Reitsamer, Alexandra Resch, Peter Schrenk, Felix Sedlmayer, Günther Steger, Herbert Stöger, Gottfried Wechselberger, Christian Weismann

The authors would like to thank the presidents of the Austrian Society of Senology (Thomas Helbich) and the Austrian Society of Surgical Oncology (Thomas Grünberger) for supporting the panel discussion. Furthermore we would like to acknowledge the following supporting societies: Austrian Society of surgery (Hans Werner Waclawiczek), Austrian society of gynecology and obstetrics (Christian Marth), Austrian society of radiation oncology (Felix Sedlmayer), Austrian society of radiology (Dimiter Tscholakoff), Austrian society of plastic, esthetic and reconstructive surgery (Thomas Hintringer) and Austrian society of pathology (Andreas Chott).

\section{References}

1 Giuliano AE, Hunt KK, Ballman KV, Beitsch PD, Whitworth PW, Blumencranz PW, Leitch AM Saha S, McCall LM, Morrow M: Axillary dissection vs no axillary dissection in women with invasive breast cancer and sentinel node metastasis: a randomized clinical trial. JAMA 2011;305:569-575.

2 Giuliano AE, Hawes D, Ballman KV, Whitworth PW, Blumencranz PW, Reintgen DS, Morrow M, Leitch AM, Hunt KK, McCall LM, Abati A, Cote R: Association of occult metastases in sentinel lymph nodes and bone marrow with survival among women with early-stage invasive breast cancer. JAMA 2011:306:385-393.

3 Vaidya JS, Joseph DJ, Tobias JS, Bulsara M, Wenz F, Saunders C, Alvarado M, Flyger HL, Massarut S, Eiermann W, Keshtgar M, Dewar J, Kraus-Tiefenbacher U, Sutterlin M, Esserman L, Holtveg HM, Roncadin M, Pigorsch S, Metaxas M, Falzon M, Matthews A, Corica T, Williams NR, Baum M: Targeted intraoperative radiotherapy versus whole breast radiotherapy for breast cancer (TARGIT-A trial): an international, prospective, randomised, non-inferiority phase 3 trial. Lancet 2010;376:91-102.
4 Veronesi U, Orecchia R, Luini A, Galimberti V, Zurrida S, Intra $\mathrm{M}$, Veronesi $\mathrm{P}$, Arnone $\mathrm{P}$, Leonardi MC, Ciocca M, Lazzari R, Caldarella P, Rotmensz N, Sangalli C, Sances D, Maisonneuve P: Intraoperative radiotherapy during breast conserving surgery: a study on 1,822 cases treated with electrons. Breast Cancer Res Treat 2010;124:141151

5 Whelan TJ, Pignol JP, Levine MN, Julian JA, MacKenzie R, Parpia S, Shelley W, Grimard L, Bowen J, Lukka H, Perera F, Fyles A, Schneider K, Gulavita S, Freeman C: Long-term results of hypofractionated radiation therapy for breast cancer. N Engl J Med 2010;362:513-520.

6 Houssami N, Macaskill P, Marinovich ML, Dixon JM, Irwig L, Brennan ME, Solin LJ: Metaanalysis of the impact of surgical margins on local recurrence in women with early-stage invasive breast cancer treated with breast-conserving therapy. Eur J Cancer 2010;46:3219-3232.

7 Dunne C, Burke JP, Morrow M, Kell MR: Effect of margin status on local recurrence after breast conservation and radiation therapy for ductal carcinoma in situ. J Clin Oncol 2009;27:1615-1620.
8 Fitzal F, Riedl O, Mittlbock M, Dubsky P, Bartsch R, Steger G, Jakesz R, Gnant M: Oncologic safety of breast conserving surgery after tumour downsizing by neoadjuvant therapy: a retrospective single centre cohort study. Breast Cancer Res Treat 2011; 127:121-128.

9 de Boer M, van Deurzen CH, van Dijck JA, Borm GF, van Diest PJ, Adang EM, Nortier JW, Rutgers EJ, Seynaeve C, Menke-Pluymers MB, Bult P, Tjan-Heijnen VC: Micrometastases or isolated tumor cells and the outcome of breast cancer. N Engl J Med 2009;361:653-663.

10 Weaver DL, Ashikaga T, Krag DN, Skelly JM, Anderson SJ, Harlow SP, Julian TB, Mamounas EP, Wolmark N: Effect of occult metastases on survival in node-negative breast cancer. N Engl J Med 2011;364:412-421.

11 Goldhirsch A, Wood WC, Coates AS, Gelber RD, Thurlimann B, Senn HJ: Strategies for subtypesdealing with the diversity of breast cancer: highlights of the St. Gallen International Expert Consensus on the Primary Therapy of Early Breast Cancer 2011. Ann Oncol 2011;22:1736-1747. 
12 Tan VK, Goh BK, Fook-Chong S, Khin LW, W ong WK, Yong WS: The feasibility and accuracy of sentinel lymph node biopsy in clinically nodenegative patients after neoadjuvant chemotherapy for breast cancer--a systematic review and metaanalysis. J Surg Oncol 2011;104:97-103.

13 Clarke M, Collins R, Darby S, Davies C, Elphinstone P, Evans E, Godwin J, Gray R, Hicks C, James S, MacKinnon E, McGale P, McHugh T, Peto R, Taylor C, Wang Y: Effects of radiotherapy and of differences in the extent of surgery for early breast cancer on local recurrence and 15-year survival: an overview of the randomised trials. Lancet 2005;366:2087-2106.

14 Pötter R, Gnant M, Kwasny W, Tausch C, Handl-Zeller L, Pakisch B, Taucher S, Hammer J, Luschin-Ebengreuth G, Schmid M, Sedlmayer F, Stierer M, Reiner G, Kapp K, Hofbauer F, Rottenfusser A, Postlberger S, Haider K, Draxler W, Jakesz R: Lumpectomy plus tamoxifen or anastrozole with or without whole breast irradiation in women with favorable early breast cancer. Int J Radiat Oncol Biol Phys 2007;68:334-340.

15 Bentzen SM, Agrawal RK, Aird EG, Barrett JM, Barrett-Lee PJ, Bentzen SM, Bliss JM, Brown J, Dewar JA, Dobbs HJ, Haviland JS, Hoskin PJ Hopwood P, Lawton PA, Magee BJ, Mills J, Morgan DA, Owen JR, Simmons S, Sumo G, Sydenham MA, Venables K, Yarnold JR: The UK Standardisation of Breast Radiotherapy (START) Trial B of radiotherapy hypofractionation for treatment of early breast cancer: a randomised trial. Lancet 2008;371:1098-1107.
16 Peters NH, van ES, van den Bosch MA, Storm RK, Plaisier PW, van DT, Diepstraten SC, Weits T, Westenend PJ, Stapper G, FernandezGallardo MA, Borel Rinkes IH, van HR, Mali WP, Peeters PH: Preoperative MRI and surgical management in patients with nonpalpable breast cancer: the MO. Eur J Cancer 2011:47:879-886.

17 Turnbull L, Brown S, Harvey I, Olivier C, Drew P, Napp V, Hanby A, Brown J: Comparative effectiveness of MRI in breast cancer (COMICE) trial: a randomised controlled trial. Lancet 2010;375:563-571.

18 Wockel A, Kreienberg R: First Revision of the German S3 Guideline 'Diagnosis, Therapy, and Follow-Up of Breast Cancer'. Breast Care 2008;3:82-86.

19 van de Vijver MJ, He YD, Van't Veer LJ, Dai H, Hart AA, Voskuil DW, Schreiber GJ, Peterse JL, Roberts C, Marton MJ, Parrish M, Atsma D, Witteveen A, Glas A, Delahaye L, van der Velde $\mathrm{T}$, Bartelink $\mathrm{H}$, Rodenhuis $\mathrm{S}$, Rutgers ET, Friend SH, Bernards R: A geneexpression signature as a predictor of survival in breast cancer. N Engl J Med 2002;347:1999-2009.

20 Paik S, Shak S, Tang G, Kim C, Baker J, Cronin M, Baehner FL, Walker MG, Watson D, Park T, Hiller W, Fisher ER, Wickerham DL, Bryant J, Wolmark N: A multigene assay to predict recurrence of tamoxifen-treated, node-negative breast cancer. N Engl J Med 2004;351:2817-2826.
Martelli G, Miceli R, Daidone MG, Vetrella G, Cerrotta AM, Piromalli D, Agresti R: Axillary dissection versus no axillary dissection in elderly patients with breast cancer and no palpable axillary nodes: results after 15 years of follow-up. Ann Surg Oncol 2011;18:125-133.

22 Rudenstam CM, Zahrieh D, Forbes JF, Crivellari D, Holmberg SB, Rey P, Dent D, Campbell I, Bernhard J, Price KN, Castiglione-Gertsch M, Goldhirsch A, Gelber RD, Coates AS: Randomized trial comparing axillary clearance versus no axillary clearance in older patients with breast cancer: first results of International Breast Cancer Study Group Trial 10-93. J Clin Oncol 2006;24:337344.

23 Song YJ, Shin SH, Cho JS, Park MH, Yoon JH, Jegal YJ: The role of lymphovascular invasion as a prognostic factor in patients with lymph nodepositive operable invasive breast cancer. J Breast Cancer 2011;14:198-203.

24 Fisher B, Anderson S, Bryant J, Margolese RG, Deutsch M, Fisher ER, Jeong JH, Wolmark N: Twenty-year follow-up of a randomized trial comparing total mastectomy, lumpectomy, and lumpectomy plus irradiation for the treatment of invasive breast cancer. N Engl J Med 2002;347:1233-1241. 